\title{
Effect of Collaborative Writing Combined With Blog Online Learning on Indonesian EFL Learners' Writing Skill Across Motivation
}

\author{
Rizki Anugrah Putri Rahayul \\ ${ }^{1}$ Corresponding author, Universitas Lampung, Indonesia;
}

Prahayu827@gmail.com

Received: January 2, $2021 \quad$ Accepted: January 20, $2021 \quad$ Published: January 20, 2021

\begin{abstract}
This study aims to investigate collaborative writing combined with blog online learning on the writing skill of Indonesian English foreign language (EFL) learners' across their motivation. This research included a quasi-experimental with the comparative time series. A quasi experimental study was employed by involving 61 learners of Senior High School. This research applied in into two groups: experimental and control. The treatment was conducted at 7 sessions, including the pre-test and post-test. The scores of pre-test and post-test in writing were used as a base of quantitative data analysis whereas the learners' responses to motivation questionnaire were used to categorize their motivation. The result revealed that the collaborative writing combined with blog online learning on the writing was effective to enhance the learners' writing skill. In addition, to apply the combination of collaborative writing and online blog learning, teacher should not worry about different levels of motivation among students where the students were motivated to use language.
\end{abstract}

Keywords: Blog Online Learning; Collaborative Writing; EFL Learners; Motivation Learners; Writing Skill

To cite this article: Rahayu, R. A. (2021). Effect of Collaborative Writing Combined with Blog Online Learning on Indonesian EFL Learners' Writing Skill across Motivation. SALEE: Study of Applied Linguistics and English Education, 2(01). https://doi.org/10.35961/salee.v2i01.219

DOI: $10.35961 /$ salee.v2i01.219 


\section{Introduction}

In this era today, writing is one of the main skills among the three other language skills. According to (Ashrafiany, Hasanuddin \& Basalama, 2015) writing is conveying information/ideas, expressing ideas towards the world, and promoting cognitive abilities. However, the writing problems experienced by students that caused by a lack of vocabulary, grammatical knowledge (Pratiwi, 2016), and low motivation in writing which influenced by ineffective teaching strategies and traditional teaching styles. Not only the phenomenon of these problems can be seen in Indonesia but also but also in the treatment of writing practice.

These problems needed a new strategy to attain the interest in writing skills such as collaborative writing. Some collaborative writing research is useful for students to spawn original ideas for students in text writing (Fuu, 2015; Sipayung, 2005).

In addition, the development of computer technology and the inclusion of internet in education are increasingly popular. EFL teachers try to use relevant material with the students. In the field of writing, a lot of research has been done to determine the effectiveness of technology towards writing. This research focused on the use of computer mediated communication (CMC) such as email, blogs, wikis, and course management systems. Some studies showed that students tend to produce better texts using technological assistance (Shang, 2007).

Blogs are text based interaction files where the students can write and edit materials on blog, many to many communication where any or all member of a group may initiate interaction with any or all of others, and time and place independent communication where user can write and receive messages at any time of the day from any computer with an internet connection (Warschauer, 1997). Blogs have the potential to collaborate, interact online, and can facilitate reading and writing activities. Research findings show blogs help and improve student writing (Awada \& Ghaith, 2014). The research finding is that students respond positively to use blog as a language learning tool (Armstrong \& Rettere, 2008, Ducate, Lara C \& Lomicka. 2008). This research deals with online learning which is done through blogs in collaborative writing. The combination of collaborative writing and learning with blog is able to solve EFL students' problems and increase their involvement in collaborative writing.

\subsection{Collaborative Writing}

Collaborative writing goes beyond the theory of social development by Vygotsky (1978). The theory helped to explain the potential of collaborative writing when it applied in teaching learning process. Learning process is a social activity and enhance through social interactions. Through their social contacts, students learn new ideas and processes that stimulate their development. It needed students' involvement when they are working. It also allowed students to learn from each other. It valued the social nature of the writing process. Based on (Show Mei Lin, 2009), students' participation followed the steps to complete the collaborative writing task: brainstorming ideas, drafting, peer feedback, revision and publishing a final draft.

According to Sukirman (2016) collaborative writing strategy is students that asked to work together in pair or group in order to produce a good writing. This strategy facilitates students to write a certain text with their peers. The term collaborative writing refers to projects where written works are created by multiple people together (collaboratively) rather than individually. It seems that collaborative writing can easy students' writing process by 
providing suitable environment while they are working together with their partners. From definitions above it can be concluded that collaborative writing is a social process that encouraged students because it involved students' social interaction when they work together in a group.

Previous studies of collaborative writing in writing have been carried out (Soraya, 2016; Villareal \& Sarratea, 2019). In addition, integrating ICT in the implementation of collaborative writing such as blogs (Recep S. Arslana \& Aysel Sahin K1z1l, 2010) has succeeded in advancing students' writing.

\subsection{Blog}

Blogs is abbreviated name for weblogs that are easily editable web pages (Zawilinski, 2009) that allowed people to create texts, as well as to upload pictures, videos and other multimedia items (Erica Boling, Jill Castek, Lisa Zawilinski, Karen Barton, \& Theresa Nierlich. 2008). Blogs have the potential to promote writing and literacy skills. Using weblogs is a useful way to join technology and education inside the classroom and outside the school walls. Because blog is both individualistic and collaborative, they are capable of providing an arena to encourage self-expression, creativity, and community building.

\subsection{Motivation in Language Learning}

Studies on the relationship between motivation and language learning have been carried out (Masyhur, 2016; Kim Bower, 2017). Janina Iwaniec, (2019) conducted a study to explore gender differences in language learning motivation. A motivation test was conducted on 599 Polish learners of English aged 14-16 and the results of Pearson's product moment correlation found a significant difference between Polish female and male learners of English in terms of their overall motivation was found, with female learners reporting higher levels of motivation than their male peers. In line with that, research on the effect of the level of motivation in writing (Areej Al- Shourafa, 2012) investigated that students with high level of motivation have better writing achievement than students with low levels of motivation.

Motivation can be defined as a force that directs and maintains goal directed behavior (Liu, Wang, \& Ryan, 2016 as cited by Yin Ling Cheung, 2018). Motivation is a sense of agency, feelings of control, students' control over learning activities and their interests in it (Julia Lo \& Fiona Hyland, 2007), while one way is to increase motivation involved students meaningfully in writing that is relevant to the social context and student culture.

Based on Chunmei Long, Zhu Ming \& Liping Chen, 2013 the role of motivation in English foreign language is to form student initiative attitudes in learning, express the great interest in learning, and focus attention in class to master knowledge in the learning process what is done in the classroom. Moreover, Motivation provided goal and direction for students and has a role in language learning. The lack of motivation resulted in several difficulties that can occur toward the students. Without the desire to learn that will have impacted on the difficulty of students to obtain in effective learning (Mitra Alizadeh, 2016).

Research studies in collaborative writing and blog projects have shared the same successful results. However, there is limited literature on the idea to incorporate blog into the use of a collaborative writing. This research also fulfills the gap from previous studies in terms of using the level of motivation as a factor that can support a strong relationship between strategy and writing skills. Therefore, in this study investigated the effect of 
collaborative writing combined with blog learning on EFL students' writing skills at the levels of motivation. This study adopted the motivation questionnaire where proposed by Nadzrah Abu Bakar, Hafizah Latif \& Azizah Ya'acob (2010). The research questions are formulated as follows:

1. Is there any difference in writing skill between EFL learners taught using collaborative writing combined with blog and those taught using the conventional method?

2. Is there any difference in writing skill between EFL learners who have a motivational level after being taught using collaborative writing combined with blogs?

\section{Method}

This study used a quasi-experimental with the comparative time series involving two groups in two classes towards senior high schools divided into experimental group and control group. This research included two variables, namely the independent variable has two variants, namely collaborative writing combined with learning through blog media as the active variable and the level of motivation as the moderating variable.

\subsection{Respondents}

The respondents of the research were classified into an experimental group consisting of 31 students randomly and a control group consisting of 30 students.

\subsection{Instruments}

This research used three instruments were writing test, scoring rubric and questionnaires. Writing test is applied to collect data about students' writing scores. The assessment rubric was adapted from Brown (2006) to create a procedural text consisting of five components: content $(30 \%)$, organization (20\%), vocabulary (20\%), language use $(20 \%)$, and mechanics $(10 \%)$. The final instrument in this study used a motivation questionnaire where adopted from Nadzrah Abu Bakar, Hafizah Latif \& Azizah Ya'acob (2010). The questionnaire tested students' motivation of using blogs as a writing platform to develop their writing skills in English. The four-point Likert scale format was used in the questionnaire.

\subsection{Procedures}

There are seven sessions in this study such as pre-test and post-test. In the pre-test conducted at the first meeting, students were asked to write a procedural text about food by choosing one of three topics such as how to make soybeans, how to make chicken soup, and how to make spinach. The topic gave where it is related to the daily life of students. In the treatment, students learned to write procedural texts in seven meetings that lasted 315 minutes where the activity can be divided into two that the first is experimental group (collaborative writing combined with blog online), and the second is control group (the conventional teaching). The collaborative writing consists of several stages such as: brainstorming given ideas what you would like to write in your group reflection, drafts started to write the draft of your reflection based on the ideas you bring up, peer feedback is provided 
feedback using the function of comment on blogs, revision is all members need to read through the draft and discuss what to delete or incorporate in your final product, and publishing a final draft.

\subsection{Data Analysis}

Pre-test and post-test were occupied to be analysed then. The pre-test data were analyzed to ensure group equality and support information about the characteristics of learners in both groups. Then, the fulfillment of statistical assumptions was carried out by testing the homogeneity and normality of the students' writing post-test scores. The results of the Levene's and Saphiro Wilk tests showed that the two groups were homogeneous and the data were in normal distribution. Therefore, the analysis on comparison of the posttest scores of the experimental and control groups as well as the comparisons of the posttest scores of subgroups high and low students' motivation was carried out using parametric statistical analysis t-test.

\section{Finding and Discussion}

\subsection{Findings}

The pre-test scores of the learners from the experimental and control groups were initially compared. The descriptive statistics of the writing pre-test from Table 1 depicted that the mean score of the experimental group was 55.97 with the standard deviation 5.62. Meanwhile, the mean score and the standard deviation of the control group was 55.60 and 5.21, respectively.

Table 1 Descriptive Statistics of the Pre-test Scores of the Learners from the Experimental and Control Groups

\begin{tabular}{lllll}
\hline Score & Group & N & Mean & Std. Deviation \\
\hline Pre-test & Experimental & 31 & 55.97 & 5.62 \\
& Control & 30 & 55.60 & 5.21 \\
\hline
\end{tabular}

The result of the comparison of the pre-test scores using independent sample t-test implied that there was no significant difference in the pre-test scores between the experimental group ( $\mathrm{p}$-value $=0.792$ ) before the treatment, meaning that the writing skill of both groups were equal.

Table 2 Comparison of the Pre-test Scores Using Independent Sample T-test

\begin{tabular}{|c|c|c|c|c|c|c|c|c|c|c|}
\hline \multicolumn{11}{|c|}{ Levene's Test For Equality of Variances } \\
\hline & & \multirow[t]{2}{*}{$\mathrm{F}$} & \multirow[t]{2}{*}{ Sig. } & \multirow[t]{2}{*}{$\mathrm{T}$} & \multirow[t]{2}{*}{ Df } & \multirow[t]{2}{*}{$\begin{array}{l}\text { Sig. 2- } \\
\text { tailed }\end{array}$} & \multirow[t]{2}{*}{$\begin{array}{l}\text { Mean } \\
\text { differ } \\
\text { ence }\end{array}$} & \multirow{2}{*}{$\begin{array}{l}\text { Std. } \\
\text { Error } \\
\text { differen } \\
\text { ce }\end{array}$} & \multicolumn{2}{|c|}{$\begin{array}{l}95 \% \text { confidence } \\
\text { interval of } \\
\text { difference }\end{array}$} \\
\hline & & & & & & & & & Lower & Upper \\
\hline $\begin{array}{l}\mathrm{P} \\
\mathrm{R} \\
\mathrm{E}\end{array}$ & $\begin{array}{l}\text { Equal } \\
\text { variances } \\
\text { assumed }\end{array}$ & , 138 & ,711 & 265 & 59 & ,792 & ,367 & 1,38 & $-2,41$ & 3,15 \\
\hline
\end{tabular}




\begin{tabular}{|l|l|l|l|l|l|l|l|l|l|}
\hline $\begin{array}{l}\text { Equal } \\
\text { variances not } \\
\text { assumed }\end{array}$ & & ,265 & 58,8 &, 792 &, 367 & 1,38 & $-2,41$ & 3,14 \\
\hline
\end{tabular}

Other result is about comparison of the post-test scores of the learners from the experimental and control groups. The descriptive statistics of post-test scores of the experimental and control groups showed that the mean score of the experimental group was 78.11 with the standard deviation 4.64. Meanwhile, the mean score and the standard deviation of the control group was 70.05 and 3.68, respectively (see Table 3). Comparing the descriptive statistics on the mean scores of the pre-test, it asserted that there was an improvement on the learners writing skill after the treatment.

Table 3 Descriptive Statistics of the Post-test Scores of the Learners from the Experimental and Control Groups

\begin{tabular}{lllll}
\hline Score & Group & $\mathrm{N}$ & Mean & Std. Deviation \\
\hline Post-test & Experimental & 31 & 78.11 & 4.64 \\
& Control & 30 & 70.05 & 3.68 \\
\hline
\end{tabular}

The independent-sample t-test was then applied to examine the effect of collaborative writing combined with blog on the learners' writing skill (RQ1) and the result was displayed in Table 4.

Table 4 Comparison of the Post-test Scores using Independent Sample T-test

\begin{tabular}{|c|c|c|c|c|c|c|c|c|c|c|}
\hline \multicolumn{11}{|c|}{ Levene's Test For Equality of Variances } \\
\hline & & \multirow[t]{2}{*}{$\mathrm{F}$} & \multirow[t]{2}{*}{ Sig. } & \multirow[t]{2}{*}{$\mathrm{T}$} & \multirow[t]{2}{*}{ Df } & \multirow[t]{2}{*}{$\begin{array}{l}\text { Sig. } \\
2- \\
\text { tailed }\end{array}$} & \multirow[t]{2}{*}{$\begin{array}{l}\text { Mean } \\
\text { differ } \\
\text { ence }\end{array}$} & \multirow{2}{*}{$\begin{array}{l}\text { Std. } \\
\text { Error } \\
\text { differen } \\
\text { ce }\end{array}$} & \multicolumn{2}{|c|}{$\begin{array}{l}95 \% \text { confidence } \\
\text { interval of } \\
\text { difference }\end{array}$} \\
\hline & & & & & & & & & Lower & Upper \\
\hline \multirow{2}{*}{$\begin{array}{l}\tilde{\sigma} \\
0 \\
0\end{array}$} & $\begin{array}{l}\text { Equal variances } \\
\text { assumed }\end{array}$ & ,967 & ,329 & 7,50 & 59 & ,000 & 8,06 & $, 1,07$ & 5,91 & 10,21 \\
\hline & $\begin{array}{l}\text { Equal variances } \\
\text { not assumed }\end{array}$ & & & 7,53 & 56,8 & ,000 & 8,06 & 1,07 & 5,92 & 10,21 \\
\hline
\end{tabular}

The statistical data in Table $4(\mathrm{p}$-value $=0.000)$ indicated that there was a significant difference on the post-test scores between the experimental and control groups of learners. The mean of the learners from the experimental group (78.11) was higher than the mean of the learners from the control group (70.05). Based on the result of the comparison of posttest scores, it can be inferred that the learners taught by using blog achieved better writing skill than those taught by using the conventional method. 


\subsubsection{Comparison of the Writing Skill between High-motivation and Low-motivation} Learners Taught by Using Blog

Since Research Question 2 is intended to determine whether the motivation level of the learners in the experimental group contributed to the effect of treatment or not, the independent sample t-test was employed and the result is shown in Table 5.

Table 5 Comparison of the Post-test Scores between High-Motivation and Low-Motivation Learners in the Experimental Group using Independent Sample T-test

\begin{tabular}{|c|c|c|c|c|c|c|c|c|c|}
\hline & \multicolumn{2}{|c|}{$\begin{array}{l}\text { Levene's Test } \\
\text { For Equality } \\
\text { of Variances }\end{array}$} & \multicolumn{7}{|c|}{$t$-tset for Equality of means } \\
\hline & \multirow[t]{2}{*}{$\mathrm{F}$} & \multirow[t]{2}{*}{ Sig. } & \multirow[t]{2}{*}{$\mathrm{T}$} & \multirow[t]{2}{*}{$\overline{\mathrm{Df}}$} & \multirow[t]{2}{*}{$\begin{array}{l}\text { Sig. } \\
2- \\
\text { tailed }\end{array}$} & \multirow[t]{2}{*}{$\begin{array}{l}\text { Mean } \\
\text { differ } \\
\text { ence }\end{array}$} & \multirow{2}{*}{$\begin{array}{l}\text { Std. } \\
\text { Error } \\
\text { differen } \\
\text { ce }\end{array}$} & \multicolumn{2}{|c|}{$\begin{array}{l}95 \% \text { confidence } \\
\text { interval of } \\
\text { difference }\end{array}$} \\
\hline & & & & & & & & Lower & Upper \\
\hline \begin{tabular}{l|l}
$\mathrm{P}$ & Equal variances \\
$\mathrm{O}$ & assumed
\end{tabular} & ,409 & ,527 & 1,26 & 29 & ,217 & 2,09 & 1,65 & $-1,29$ & 5,48 \\
\hline $\begin{array}{ll}\mathrm{S} & \text { Equal variances } \\
\mathrm{T} & \text { not assumed }\end{array}$ & & & 1,27 & 28,4 & ,214 & 2,09 & 1,64 & $-1,28$ & 5,47 \\
\hline
\end{tabular}

The comparison as shown in Table 5 revealed that there was no significant difference in the writing skill of the learners with high and low-motivation levels ( $p$-value $=0.217$ ). In conclusion, the categorization of motivation level (high and low) had no effect on the writing skill of the learners taught by collaborative writing combined with blog.

\subsubsection{Students' Response to Motivation}

The percentage analyze showed toward 61 response questionnaire accomplished by 61 students in Senior High School. For the questions of questionnaire was from 1 to 7 where adopted from Nadzrah Abu Bakar, Hafizah Latif \& Azizah Ya'acob (2010) which are showed on the following table:

Table 6 the percentage (\%) students' response to Motivation using the blog towards writing skill

\begin{tabular}{llllll}
\hline No & Statements & $\begin{array}{l}\text { Strongly } \\
\text { Agree }\end{array}$ & Agree & Disagree & $\begin{array}{l}\text { Strongly } \\
\text { Disagree }\end{array}$ \\
\hline 1 & $\begin{array}{l}\text { I think it is a good idea to use blogs to } \\
\text { practice writing skills in English. (Q1) }\end{array}$ & $90,4 \%$ & $9,6 \%$ & $0 \%$ & $0 \%$ \\
\hline 2 & $\begin{array}{l}\text { Blogging helps me how to write better in } \\
\text { English.(Q2) }\end{array}$ & $9,7 \%$ & $80,3 \%$ & $0 \%$ & $0 \%$ \\
\hline 3 & $\begin{array}{l}\text { I can express my ideas freely through } \\
\text { blogging. (Q3) }\end{array}$ & $9,9 \%$ & $90,1 \%$ & $0 \%$ & $0 \%$ \\
\hline 4 & $\begin{array}{l}\text { By active participation in blogging I can } \\
\text { be more creative in expressing my ideas. } \\
\text { (Q4) }\end{array}$ & & & $0 \%$ \\
\hline 5 & $\begin{array}{l}\text { Blogging helps me to be more motivated } \\
\text { and interested in writing. (Q5) }\end{array}$ & $9,8 \%$ & $0,2 \%$ & $0 \%$ & $0 \%$ \\
\hline 6 & $\begin{array}{l}\text { I can write longer in English using } \\
\text { weblog. (Q6) }\end{array}$ & $9,3 \%$ & $70,7 \%$ & $0 \%$ & $0 \%$ \\
\hline
\end{tabular}




\begin{tabular}{llllll}
\hline 7 & $\begin{array}{l}\text { I think my English grammar has } \\
\text { improved by weblog-based collaborative } \\
\text { writing. (Q7) }\end{array}$ & & & & \\
\hline
\end{tabular}

The result of students' response motivation showed the high percentage of the students chose "Strongly Agree" and "Agree" than "Disagree" and "Strongly Disagree". Furthermore, from the calculation of questionnaire can be discovered the most students have highly motivation in writing skill using blog online learning.

\subsection{Discussion}

Referring to the research findings on statistical analysis using the t-test, it was found that students who were taught with collaborative writing combined with blogs had better writing skills than those taught by conventional methods. The results of data analysis are presented with reference to two research questions. The effectiveness of the application of collaborative writing combined with blog learning in learning to write procedural texts is caused by several aspects.

First, collaborative writing provided opportunities for the involvement of students in writing text confidently. With regard to the first research question, the results of this study indicate that collaborative writing combined with blog learning is effective for developing foreign language learning. This evidenced by the results of the post test which showed that there are significant differences in the writing ability of students.

These results support the findings of previous research on the application of collaborative writing that this strategy is effective in improving the writing skills of students (Izaskun Villarreal \& Nora Gil-Sarratea, 2019; Rezy Anggraini, Yenni Rozimela, \& Desvalini Anwar, 2020). Meanwhile, differences were also found in the combination of ICT media. Based on Zsuzsanna I Abrams (2020) integrated collaborative writing with Google docs, Maha Alghasab, Jan Hardman, \& Zoe Handley (2019) with a wiki. On the other hand, this study tried to combine collaborative writing with blog. Comparable to these findings, in terms of implementing collaborative writing, this study shows the same successful results.

Second, blog is as an ICT medium for finding information that helped students generate ideas at the writing process stage. This is in accordance with the integration of ICT and the internet in an effective language classroom to improve the writing performance of students Cahyono and Mutiaraningrum (2016). In addition, this is evidence that supported previous research on the benefits of blogs in helping language learning (Jo Mynard, 2007; Pamela Pane, 2014; Muge Gunduz, 2016). The idea of incorporating media in writing activities proved to be a good choice in promoting the language performance of students. This concept reinforced the theory that blog encouraged student participation (Zaini Amir, Kemboja Ismail \& Supyan Hussin, 2011; Wenting Chen, 2019).

The second research question discussed the comparison of writing skills between students with high and low motivation in the experimental group. Previously, it has been discussed that blog learning has provided significant results in improving students' writing skills. Conversely, the results of the comparison of high and low student motivation in the experimental group showed that there was no significant difference in the posttest scores (pvalue $=0.217$ ). The findings in this study are different from the findings of research 
conducted by Areej Al-Shourafa, (2012) which revealed that students who have high motivation have better writing achievement than students who have low motivation. Meanwhile, the current research showed that the writing skills of students who have high and low motivation after getting collaborative writing combined with blog learning treatment is the same. Thus, this finding is supported by the reason that blog facilitated written communication because students can read, write and edit text posts on blogs. Thus, students with high and low levels of motivation have the same opportunity to revise writing.

\section{Conclusion}

This study examined the effect of collaborative writing combined with blog learning at all levels of motivation. Blog can be chosen as an alternative to teaching foreign language writing. The effectiveness of the blog is supported by several factors, namely: the involvement of students, assisting learning blogs as a source of information and learning material, making procedural texts as an opportunity to display students' writings, and a relaxed atmosphere during treatment. The results of the successful application of blogs on the writing skills of Indonesian EFL students, it is known that the writing skills of students are with the high and low motivations in experimental group are not significantly different. Interestingly, it can be reported that low levels of motivation can develop their writing skills as well as students with high motivation. This suggests that whenever EFL teachers want to implement a learning blog they don't have to worry about the motivation level of their learners. 


\section{References}

Ashrafiany, Hasanuddin, \& Basalama, Nonny. (2015). The Students' Writing Difficulties In Writing An Essay Based On Cognitive Process. Lingua Jurnal Pendidikan Bahasa. Vol. 16. No. 1.

Alizadeh, Mitra. (2016). The Impact of Motivation on English Language Learning. International Journal of Research in English Education. Vol. 1. No. 2.

Awada, Ghada \& Ghaith, Ghazi. (2014). Effect of Using the Blog Educational Tool on Writing Achievement and Motivation for Legal Writing. International Journal of Education and Research. Vol. 2 No. 12.

Anggraini, Rezy, Yenni Rozimela, \& Desvalini Anwar. (2020). Collaborative Writing in Writing Process: How Effective?. Social Science, Education and Humanities Research. Vol. 463.

Areej Al Shourafa. (2012). The Effect of Motivation on Jordanian 10th Grade Students' Writing Skill in English. European Scientific Journal. Vol. 8. No.22.

Armstrong, Kimberly \& Oscar Retterer. (2008). Blogging as L2 Writing: A Case Study. AACE Journal. Vol. 16. No.3.

Brown, H. D. (2006). Language assessment: Principles and classroom practices. New York: Longman.

Cahyono, Bambang Yudi, \& Ira Mutiaraningrum. (2016). Indonesian EFL Teachers' Familiarity with and Opinion on the Internet Based Teaching of Writing. English Language Teaching, 9 (1), 199.

Dale, Helen. (1997) Co-Authoring In The Classroom: Creating An Environment For Effective Collaboration. Illinois: Viepoints.

Ducate, Lara C and Lara L. Lomicka. 2008. Adventures in the blogosphere: from blog readers to blog writers. Computer Assisted Language Learning. Vol. 21, No. 1.

Erica Boling, Jill Castek, Lisa Zawilinski, Karen Barton, \& Theresa Nierlich. (2008). Collaborative Literacy: Blogs and Internet Projects. Technology in Literacy Education Technology in Literacy Education. Vol. 61. No. 6.

Hyland, K. (2003). Second Language Writing. Cambridge: Cambridge University Press.

Jui, Hui Fuu. (2015). The Effects of Blog-Supported Collaborative Writing on Writing Performance, Writing Anxiety And Perceptions of Efl College Students In Taiwan. University of South Florida Scholar Commons.

Janina Iwaniec. (2019). Language learning motivation and gender: The case of Poland. No. 29.

Julia Lo \& Fiona Hyland. 2007. Enhancing students' engagement and motivation in writing: The case of primary students in Hong Kong. Journal of Second Language Writing. Vol. 16.

Jo Mynard. (2007). A blog as a Tool for Reflection for English Language Learners. Asian EFL Journal. 
Kim Bower. (2017). Explaining motivation in language learning: a framework for evaluation and research. The Language Learning Journal.

Lin, Show Mei. (2009). How Computer Mediated Communication Affects Ell Students' Writing Processes And Writing Performance. Unpublished Doctoral Dissertation, University of Oklahoma, Norman.

Long Chunmei, Zhu Ming \& Liping Chen. (2013). The Study of Student Motivation on English Learning in Junior Middle School -- A Case Study of No.5 Middle School in Gejiu. English Language Teaching. Vol. 6. No. 9.

Masyhur. (2016). Influence Of Motivation And Language Learning Environment On The Successful Efl Learning. Proceedings of the Fourth International Seminar on English Language and Teaching. Vol. 4. No. 2.

Nadzrah Abu Bakar, Hafizah Latif \& Azizah Ya'acob. (2010). ESL Students feedback on the use of blogs for language learning. Journal of English Language Studies. Vol. 16.

Pamela Pane. (2014). How Does the Use of Blogs Impact Student Motivation for Literature Discussions? Journal of Inquiry \& Action in Education, Vol. 5. No. 3.

Pratiwi, Kristy Dwi. (2016). Students' Difficulties in Writing English (A Study at the Third Semester Students of English Education Program At University of Bengkulu Academic Year 2011-2012). Journal of Linguists and Language Teaching. Vol 3, No 1.

Recep S. Arslana \& Aysel Sahin K1z1l, (2010). How can the use of blog software facilitate the writing process of English language learners?. Computer Assisted Language Learning. Vol. 23. No. 3.

Sipayung, Kammer Tuahman. (2005). The Implementation of Collaborative Writing Method to Improve Students' Writing of Descriptive Genre at SMP Negeri 3 Percut Sei Tuan on Grade VIII at the Accademic Year 2015/2016. Jurnal Suluh Pendidikan. Vol. 3.

Soraya, Kiky. (2016). The Effectiveness Of Collaborative Writing Strategy (Cws) In Writing Lesson Regarded To The Students' Creativity. Lingua Cultura, 10(2).

Stephen D, Krashen. (1982). Principles and Practice in Second Language Acquisition. Research Gate.

Sukirman. (2016). Using Collaborative Writing in Teaching Writing. Langkawi. Vol. 2. No.1.

Shang, Hui Fang. (2007). An Exploratory Study Of E-Mail Application On Fl Writing Performance. Computer Assisted Language Learning, Vol. 20. No.1.

Vygotsky, L. S. (1978). Mind In Society: The Development Of Higher Psychological Processes. Ma: Harvard University Press.

Villareal, Izaskun \& Sarratea, N.G. (2019). The Effect of Collaborative Writing in an EFL Secondary Setting. Language Teaching Research.

Warschauer, Mark. (1997). Computer Mediated Collaborative Learning: Theory and Practice. The Modern Language Journal, Vol. 80. No.4. 
Yin Ling Cheung. (2018). The Effects of Writing Instructors' Motivational Strategies on Student Motivation. Australian Journal of Teacher Education. Vol. 43.

Zawilinski, Lisa. (2009). HOT Blogging: A Framework for Blogging to Promote Higher Order Thinking. The Reading Teacher. Vol. 62. No. 8

Zaini Amir, Kemboja Ismail \& Supyan Hussin. (2011). Blogs in Language Learning: Maximizing Students' Collaborative Writing. Procedia Social and Behavioral Sciences. Vol. 18.

Zsuzcasama, I. (2019). Writing and Text Quality in Google Docs. Language Learning \& Technology. Vo. 23. 